\title{
The thermal dehydroxylation of kaolinite using thermogravimetric analysis and Controlled rate thermal analysis.
}

\author{
MBEY Jean Aimé ${ }^{\prime *}$, NGALLY SABOUANG Cyrill Joël${ }^{2}$, MAKON Thomas Beauregard ${ }^{1}$, \\ COULIBALY Sandotin Lassina ${ }^{3}$ and KONG Sakéo ${ }^{1}$ \\ ${ }^{1}$ University of Yaoundé 1, Laboratory of Applied Inorganic Chemistry, P.O. Box 812 Yaounde- \\ Cameroon \\ ${ }^{2}$ University of Bamenda, Higher Teacher Training College, Po Box 39 Bambili, Cameroon; \\ cngally@yahoo.fr \\ ${ }^{3}$ University of Man, School of Mining and Energy, P.O. Box 20 Man-Ivory Coast \\ *Corresponding author: mbey25@yahoo.fr
}

\begin{abstract}
The aim of this work was to identify parameters that could influence the conversion of kaolinite into metakaolinite. To this end, the dehydroxylation of four kaolinites, using controlled rate thermal analysis (CRTA) and thermogravimetric analysis (TGA), was investigated. X-ray diffraction (XRD) and Fourier transform infra-red (FTIR) were used to confirm the kaolinitic nature of the samples. Their crystallinity was evaluated using the Hinckley index from the X RD patterns and transmission electron microscopy (TEM) was used for morphological observation of the clay platelets. The thermal analyses of the samples indicate, for all samples, low defects as revealed by the low amount of adsorbed water on the clay surface. The dehydroxylation temperature from both techniques was influenced by the sample crystallinity and particle size. It was observed from both techniques that increase crystallinity resulted in high dehydroxylation temperature. Also, the influence of the clay platelets size on the dehydroxylation temperature, is proposed. All the results indicate that crystallinity and particle size are parameters that could be used to control the temperature for the conversion of kaolinite to metakaolinite.
\end{abstract}

Keywords: Kaolinite; Crystallinity, Dehydroxylation; Thermal analysis

Received: 4/ 11/ 2020

Accepted: 08/ 03/ 2021

D OI: https/ / dx.doi.org/ 10.4314/ jcas.v16i4

(1) The Authors. This work is published under the Creative Commons Attribution 4.0 International Licence. 


\section{Résumé}

L'objectif du présent travail était d'identifier les paramètres qui influencent la température de conversion de la kaolinite en métakaolinite. Pour ce faire, l'analyse thermogravimétrique (ATG) et l'analyse thermique à vitesse contrôlée (ATVC) sont utilisées pour étudier la déhydroxylation de quatre échantillons de kaolinites. Au préalable, la diffraction des rayons X (DRX) et l'analyse infra-rouge à transformée de Fourier (IRTF) ont été utilisées pour confirmer la nature kaolinique de ces échantillons. La cristallinité des échantillons est évaluée par mesure de l'indice d'Hinckley à partir des spectres D RX et la microscopie électronique à transmission (MET) est utilisée pour l'analyse morphologique des échantillons. Les différentes analyses thermiques indiquent, pour tous les échantillons, un faible taux de défauts structuraux mis en évidence par une faible perte de masse relative à l'eau libre adsorbée en surface. La température de déhydroxylation mesurée par les deux techniques est influencée par la cristallinité. Il apparait que la température de déhydroxylation s'élève avec une augmentation de la cristallinité. Une influence de la taille des particules d'argile sur la déhydroxylation a été observée. Il ressort que, la cristallinité et la taille des particules sont des paramètres qui peuvent être utilisés pour contrôler la conversion de la kaolinite en métakaolinite.

Mots clés: Kaolinite; Cristallinité; déhydroxylation; analyse thermique 


\section{Introduction}

Clays are minerals, widely used in industries for various applications including building materials, fillers in plastics, paper, polymer-clay composite (De Carvalho et al., 2001; Harvey and Lagaly, 2006; Ekosse, 2010; Nkoumbou et al., 2009; Fadil-Djenabou et al., 2015; Gul et al., 2016). The applications of clay are associated to their properties such as their specific surface area, their swelling properties, their surface charges, and their shape anisotropy. For application in polymercomposite for example, clays from the smectite group are the most suitable due to their intrinsic capacity to expand and to delaminate into individual clay platelets ( $\mathrm{Gul}$ et al., 2016; La Mantia et al., 2015; Uysal et al., 2014). In paper industry, kaolinitic clay are prefer due to their high purity and brightness (Murray, 2000). For an efficient economic use of any clay, its availability is the key. The geological deposits for smectites clay are scarce in comparison to kaolinites, which are ubiquitous clays largely exploited as industrial minerals in various domains including paper, plastics, rubber, fiber glass, pesticides, building or ceramics (Murray, 2000; Harvey and Lagaly, 2006). Despite their reduced expandability, they are also regarded as potential candidates for polymer-clay composites making (Chen and Evans, 2005; Mbey et al., 2012; Mbey et al., 2013; Mbey and Thomas, 2015).

The kaolinite layer $\mathrm{Al}_{2} \mathrm{Si}_{2} \mathrm{O}_{5}(\mathrm{OH})_{4}$ is formed by the superposition of one sheet of aluminum hydroxide in octahedral symmetry, and one sheet of silicon oxide in tetrahedral symmetry. Thus, a kaolinite layer has asymmetrical basal planes with siloxane and aluminol groups. The superposition of kaolinite layers generates strong hydrogen bonds between the siloxane groups of one layer and the aluminol groups of the next layer, and hence strong cohesive energy between the layers (Giese, 1988; Cabedo et al., 2004). Kaolinite particles therefore occur as non-expandable, large layer stacks of low anisotropy with relative high density that justified their applications in ceramic and building material such as fired bricks or cementitious product making. For such application, their thermal conversion in metakaolinite, an amorphous intermediate of great interest for pouzzolanic reaction is a key (Tchakouté Kouamo et al., 2012; Ndjigui et al., 2016; O nana et al., 2019; Djon li Njock et al., 2021).

Natural occurring kaolinite clays are characterized by several types of imperfections, which may influence the strength of the $\mathrm{H}$-bonds between the clay sheets. The difference may be due to chemical substitutions in the crystal network and by stacking faults. The geologic origin of the sample mainly determines these imperfections. Kaolinites of hydrothermal origin have low rates of substitutions and high stacking order, whereas sedimentary kaolinites are more substituted and show degraded stacking order. Hence, the conversion of a kaolinite in metakaolinite may be influenced by some of its crystallochemical parameters. Also, the firing technique may affect the dehydroxylation temperature of the sample. Identifying parameters affecting kaolinitemetakolinite conversion may help reducing the firing temperature and by so doing, the energy consumption. In the present study, four kaolinite samples of different crystallinity and of different geological environment were used for a comparison of their conversion into metakaolinite using controlled rate thermal analysis (CRTA) and thermogravimetric analysis (TGA).

\section{Materials and Methods}

A Cameroonian kaolinite from Mayouom (MY3) is selected and studied together with two reference kaolinites from the Clay Minerals Society (MAC and Kga2) and one kaolinite from the Charente deposit (France) (GZA4). The samples were wet sieved over a $40 \mu \mathrm{m}$ mesh. The obtained cakes were dried at room temperature, then in an oven at $70^{\circ} \mathrm{C}$ for 24 hours, and stored in polyethylene bags before experimentation. The sources of the kaolinites and their BET (Brunauer, Emmett and Teller) specific surface area (SSA) (from nitrogen adsorption) are given 
in Table 1 (Mbey et al., 2019). The Hinckley Index (H.I.), determined from their XRD patterns, are also given in table 1. This index is a measure of the kaolinite crystallinity. When the Hinckley index is closed to one, the sample is well crystallized (Hinckley, 1963).

Powder X-Ray diffraction patterns were recorded using a D 8 Advance Bruker diffractometer equipped with a Co Ká radiation $(l=1.7890 \AA)$ operating at $35 \mathrm{kV}$ and $45 \mathrm{~mA}$. The diffraction patterns were obtained from $1.5^{\circ}$ to $32^{\circ}$ at a scanning rate of 0.035 per $323.9 \mathrm{~s}$.

Infrared spectra were recorded in diffuse reflectance mode using a Bruker Fourier Transform Interferometer IFS 55. The spectra were recorded from $4000 \mathrm{~cm}^{\prime 1}$ to $600 \mathrm{~cm}^{\prime 1}$ with a resolution of $4 \mathrm{~cm}^{\prime \prime}$. Each spectra is obtained as an accumulation of 200 scans. Potassium bromide (KBr) pellets containing $~ 10 \%$ of the powder clay were obtained by pressing (10 tons/ $\left.\mathrm{cm}^{2}\right)$ manually ground mixtures of the clay and oven dried potassium bromide.

For thermogravimetric analysis, a LINSEIS (model STA PT-1000) apparatus, operating under an air flow was used for TGA-DTG data acquisition. The samples were placed in an alumina crucible and heated from ambient to 800 ${ }^{\circ} \mathrm{C}$ at a heating rate of $10{ }^{\circ} \mathrm{C} \cdot \mathrm{min}{ }^{\prime 1}$.

The Control Rate Thermal data were acquired on a homemade apparatus at Laboratoire Interdisaiplinaire des Envirannements continentaux (LIEC, Nancy-France) equipped with a mass spectrometer. In CRTA, the temperature increase is not imposed but in controlled by the reaction rate through pressure measurement. The sample was placed under dynamic vacuum through a micro leak. The limiting pressure was fixed at 2 $\mathrm{Pa}$, which ensures a linear weight loss with time (Feylessoufi et al., 1996).

The morphology was analysed on Transmission electron microscope (TEM) using a Philips CM20 microscope operating at $200 \mathrm{KV}$.

Table 1: Sources, chemical analysis, specific surface area (SSA) and Hinckley Index (H.I.) of the studied kaolinite samples

\begin{tabular}{|c|c|c|c|c|}
\hline $\begin{array}{l}\text { Samples } \\
\text { names }\end{array}$ & MY3 & GZA4 & Kga2 & MAC \\
\hline Sources & $\begin{array}{l}\text { Cameroon } \\
\text { (Mayouom) }\end{array}$ & $\begin{array}{l}\text { France } \\
\text { (Charentes) }\end{array}$ & $\begin{array}{l}\text { USA } \\
\text { (G eorgia) }\end{array}$ & $\begin{array}{l}\text { USA (Macon, } \\
\text { Georgia) }\end{array}$ \\
\hline SSA $\left(\mathrm{m}^{2} / \mathrm{g}\right)$ & 25.9 & 24.9 & 21 & 18.7 \\
\hline H.I. & 1.05 & 0.57 & 0.44 & 0.86 \\
\hline \multicolumn{5}{|c|}{ Chemical Analysis of Major elements } \\
\hline $\mathrm{SiO}_{2}$ & 44.28 & 45.47 & 43.89 & 45.20 \\
\hline $\mathrm{Al}_{2} \mathbf{O}_{3}$ & 34.21 & 36.66 & 37.37 & 36.65 \\
\hline $\mathrm{Fe}_{2} \mathrm{O}_{3}$ & 1.97 & 1.27 & 1.17 & 0.44 \\
\hline MnO & 0.01 & 0.00 & 0.00 & 0.00 \\
\hline Mg0 & 0.24 & 0.11 & 0.03 & 0.27 \\
\hline $\mathrm{CaO}$ & 0.04 & 0.18 & $<$ L.D & 0.26 \\
\hline $\mathrm{Na}_{2} \mathrm{O}$ & $<$ L.D & 0.04 & $<$ L.D & $<$ L.D \\
\hline $\mathrm{K}_{2} \mathrm{O}$ & 1.23 & 0.57 & 0.04 & 0.02 \\
\hline $\mathrm{TiO}_{2}$ & 3.39 & 1.21 & 2.17 & 1.50 \\
\hline $\mathbf{P}_{2} \mathbf{O}_{5}$ & 0.26 & 0.06 & 0.05 & $<$ L.D \\
\hline LOI & 13.70 & 14.01 & 14.29 & 14.67 \\
\hline T otal & 99.33 & 99.59 & 99.01 & 99.01 \\
\hline
\end{tabular}




\section{Results and discussions}

Minaralogical Charadteization of the kadinite samples

From the XRD patterns (Figure 1) and the FTIR spectra (Figure 2), the kaolinitic nature of all the samples is evidenced. The calculated basal distances are coherent with a mineralogical assemblage made of kaolinite, illite and rutile. The reflection at $16.33 \AA$ was assigned, in a previous study, to a kaolinite-illite interstratification (Mbey et al., 2019). The calculated Hinckley Crystallinity Index (HI) indicates that MY3 is the better crystallized samples, followed by sample MAC. Samples GZA4 and Kg2 are poorly crystallized samples.

The infra-red spectra (Figure 2) confirm the X RD results. The spectra are typical of kaolinitic clays with the stretching bands of $\mathrm{O}-\mathrm{H}$ bonds, in the kaolinite structure, at 3697, 3666, 3651 and 3620 $\mathrm{cm}^{-1}$ (Frost et al., 2001; Mbey et al., 2013). The group deformation vibration bands of free water molecules within the samples are observed at 1915 $\mathrm{cm}^{-1}, 1816 \mathrm{~cm}^{-1}$ and $1625 \mathrm{~cm}^{-1}$. Their low intensities are indicative of relative low adsorbed water which is coherent with relative low defects generally encountered in kaolinitic clay. Characteristics vibration bands for $\mathrm{Si}-\mathrm{O}$ stretching and $\mathrm{Si}-\mathrm{O}-\mathrm{Si}$ skeleton stretching vibration are present, respectively, at $1111 \mathrm{~cm}^{-1}$ and at $1016 \mathrm{~cm}^{-}$ ${ }^{1}$. Also, the bending vibration of $\mathrm{Al}-\mathrm{OH}$ at 917 $\mathrm{cm}^{-1}$ and the $-\mathrm{OH}(\mathrm{Al}-\mathrm{OH})$ translational vibrations at $786 \mathrm{~cm}^{-1}, 748 \mathrm{~cm}^{-1}$ and $694 \mathrm{~cm}^{-1}$ are registered (Q taitat and Al-Trawneh, 2005). All the structural vibrations are coherent with the alumino-silicate nature of the samples. On the Kga2 spectrum, a band at $3427 \mathrm{~cm}^{-1}$ is registered and it is associated to the $\mathrm{O}-\mathrm{H}$ of a hydroxyl that is linked to iron. This band is suggesting the presence of trace goethite in $\mathrm{Kag} 2$.

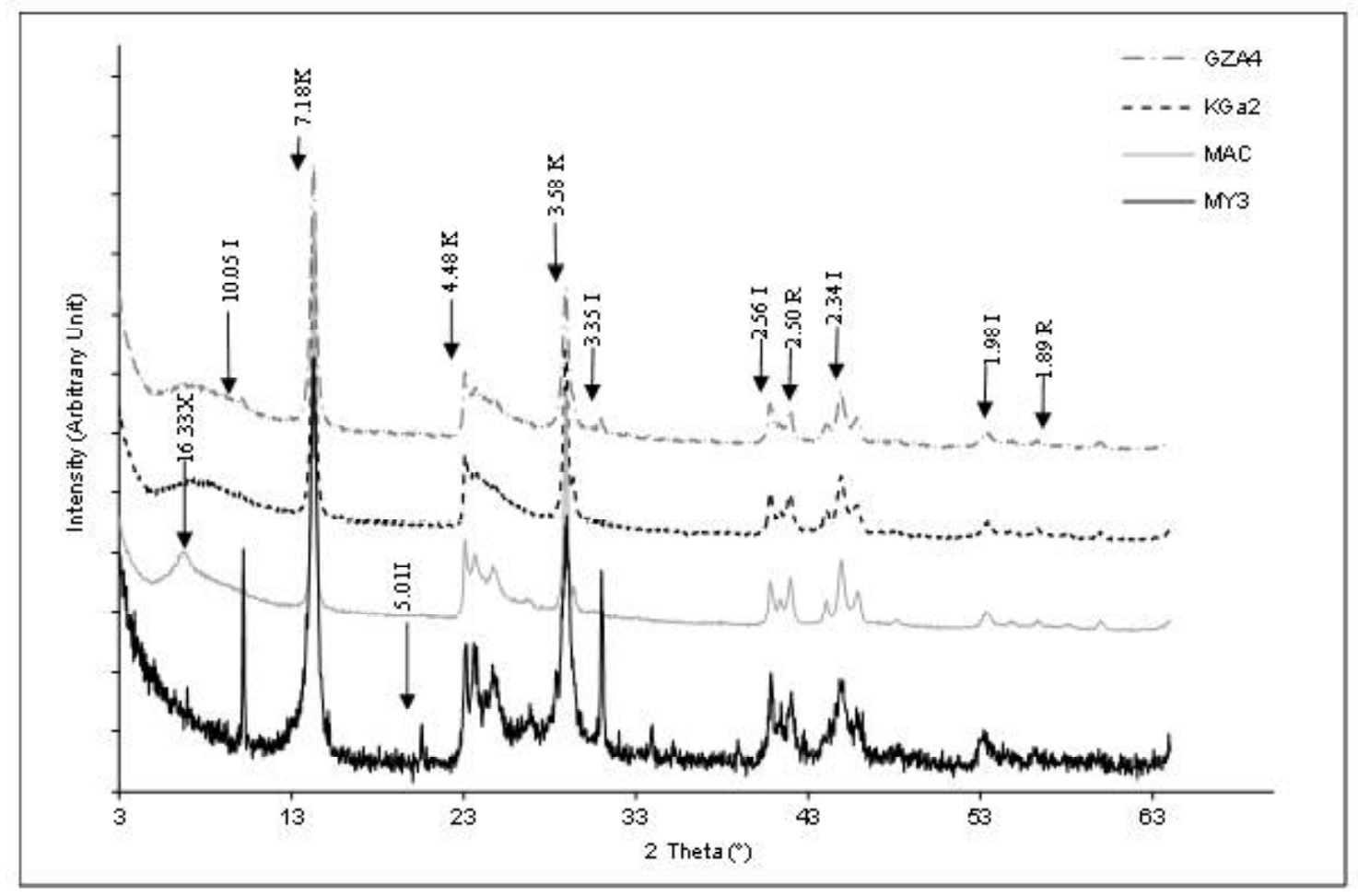

K: Kaolinite; I: Illite; R: Rutile

Figure 1: XRD patterns of the kaolinite samples 


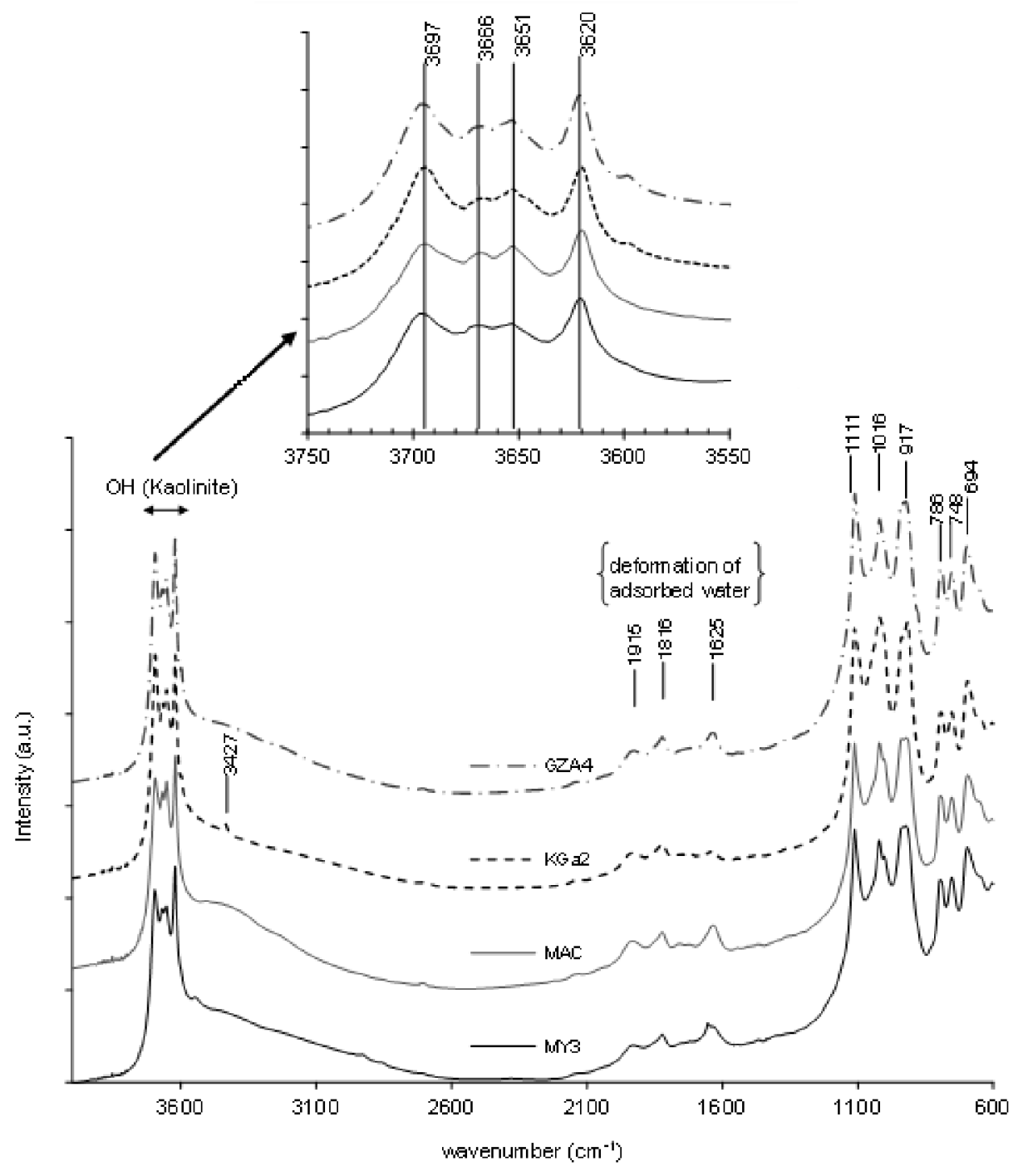

Figure 2: FTIR spectra of the kaolinite samples

\section{Micographic dbservations}

The samples TEM micrographs are presented in Figure 3. It appears that the hexagonal feature of kaolinite platelets is obvious from all the images. The size of the grain on the images indicates that MAC is formed of larger platelets followed by Kga2. The finest samples are MY 3 and GZA4. The TEM observations are in line with the samples SSA which decrease as follows: MY $3>$ GZA4 > Kga2 > MAC (Table1). 

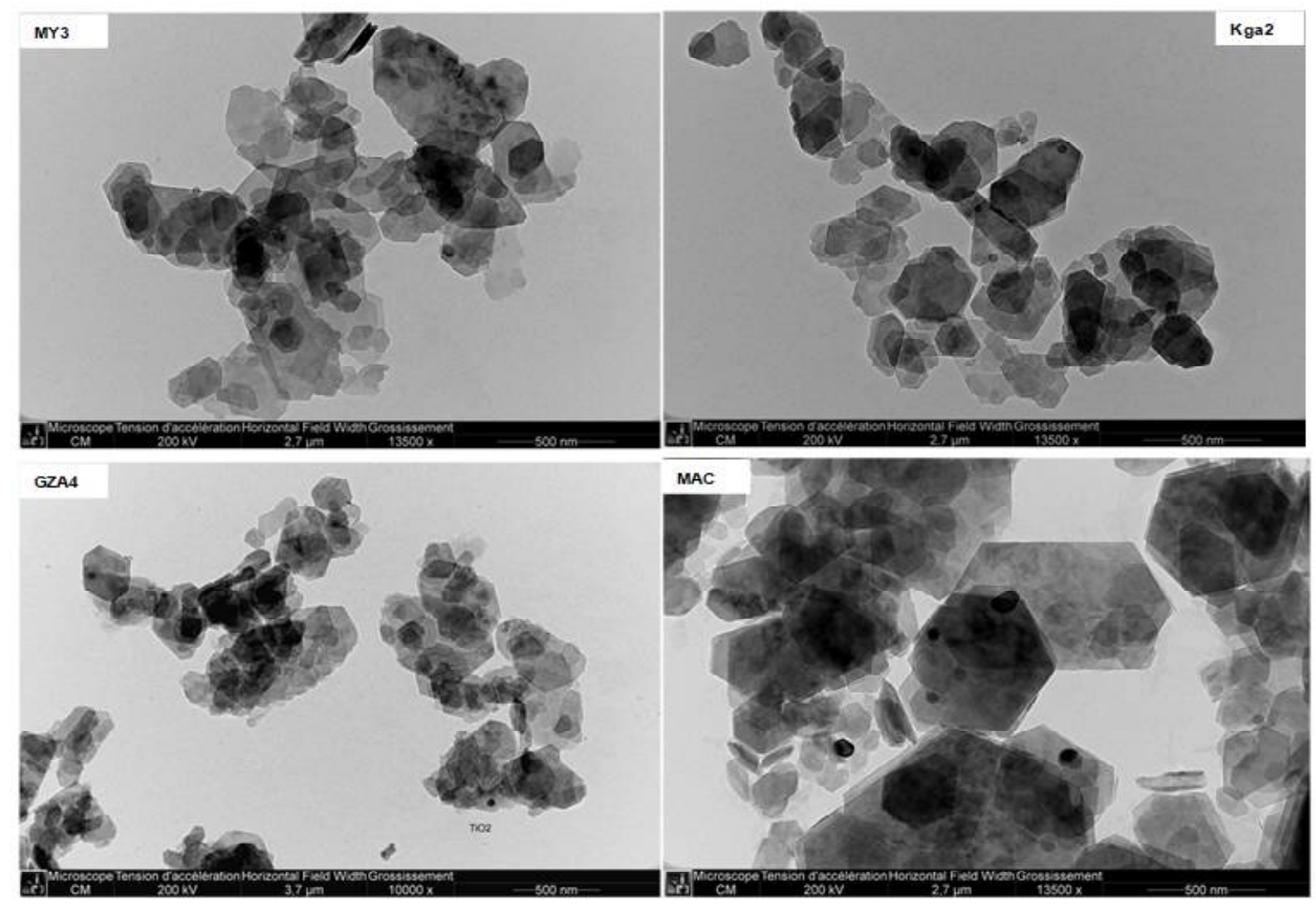

Figure 3: TEM micrographs of the kaolinite samples

\section{Themml Analysis}

The DTG / TGA and the CRTA thermograms are given, respectively, on Figure 4 and figure 5. Both figures show a release of adsorbed water molecules on the external surface of kaolinite at temperature lower that $80{ }^{\circ} \mathrm{C}$. This low temperature for adsorbed water released is coherent with the absence of intercalated water molecules. Kaolinite, usually, does not allow interlayer cations, which are responsible of the adsorption of water in the interlayer of clays.

The mass losses during kaolinite dehydroxylation on TGA thermograms (Figure 4a), have values that are within the range of the values (between 10 and $13.9 \%$ ), which are usually reported for kaolinite (G asparini et al., 2013; Zhang et al., 2012; Frost et al., 2010). From these mass losses, $\mathrm{Kga}$, with the highest value (12.6\%), is the closest to the value for ideal kaolinite (13.9\%). The difference in the water loss is associated to defect in the kaolinite structure (Frost et al.,
2010). Hence, the least defects are attributed to $\mathrm{Kga} 2$ and this agrees with the calculated sample formula in a previous study (Mbey et al., 2019).

From the DTG curves (Figure $4 \mathrm{~b}$ ), the dehydroxylation temperature for MY 3 , K ga2, GZA4 and MAC appear at $527^{\circ} \mathrm{C}, 520^{\circ} \mathrm{C}, 520$ ${ }^{\circ} \mathrm{C}$ and $532{ }^{\circ} \mathrm{C}$, respectively. $\mathrm{On}$ the CRTA curves (Figure 5) the dehydroxylation of the kaolinite occurs at $396{ }^{\circ} \mathrm{C}, 382{ }^{\circ} \mathrm{C}, 392{ }^{\circ} \mathrm{C}$ and $398{ }^{\circ} \mathrm{C}$, respectively, for MY3, Kga2, GZA4 and MAC. It is observed that the DTG temperature values are higher than those of CRTA. This difference is due to the operating conditions. The DTG/ TGA analysis was carried out under air flow, while CRTA was done under high-vacuum. In both DTG and CRTA, the values are within a narrow range although a more noticeable difference is registered for CRTA values. The better crystallized samples, MY 3 and MAC, with crystallinity index of 1.05 and 0.86 (Table 1), exhibit the highest dehydroxylation temperature in both DTG and 
CRTA. The lowest dehydroxylation temperature is registered for the $\mathrm{Kga} 2$, which has the lowest crystallinity index in both DTG and CRTA. Combining DTG and CRTA results, it could be concluded that $\mathrm{Kga} 2$ has the lowest dehydroxylation temperature. Hence, low crystallinity leads to low dehydroxylation temperature. Frost et al. (2010), in a study using DTA also observed similar results. Giving that crystallinity is associated to stacking order and hence to the internal interactions, the influence of crystallinity on dehydroxylation temperature is obvious. However, considering MAC and MY3,

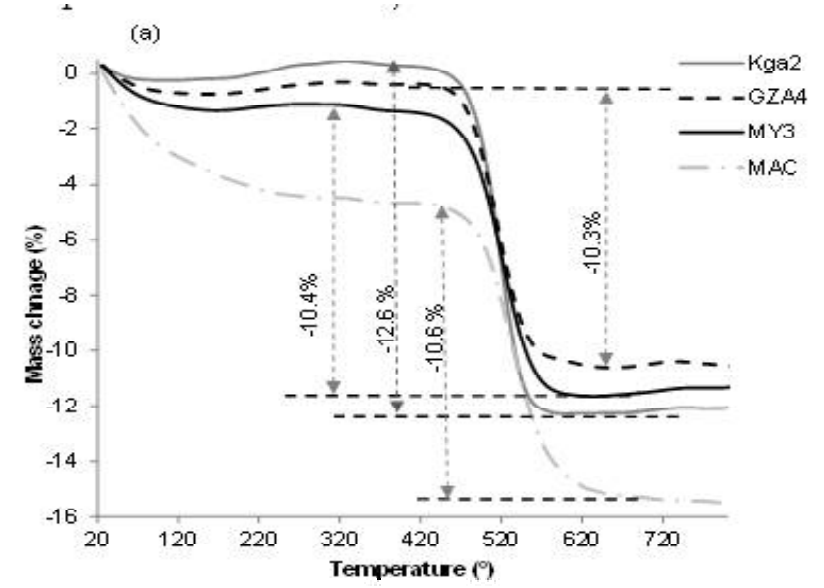

although MY 3 is better crystallized, its dehydroxylation temperature is lower than that of MAC. Hence, crystallinity alone may not be sufficient. It is suggested that one may also take in account the clay particle size within the sample as the heat diffusion may be slowed with the thickness. From the SSA, MAC with the lowest value of $18 \mathrm{~m}^{2} / \mathrm{g}$ is formed of larger particle than MY 3 as also observed from TEM (Figure 3), hence the high dehydroxyalation temperature for MAC is justified.

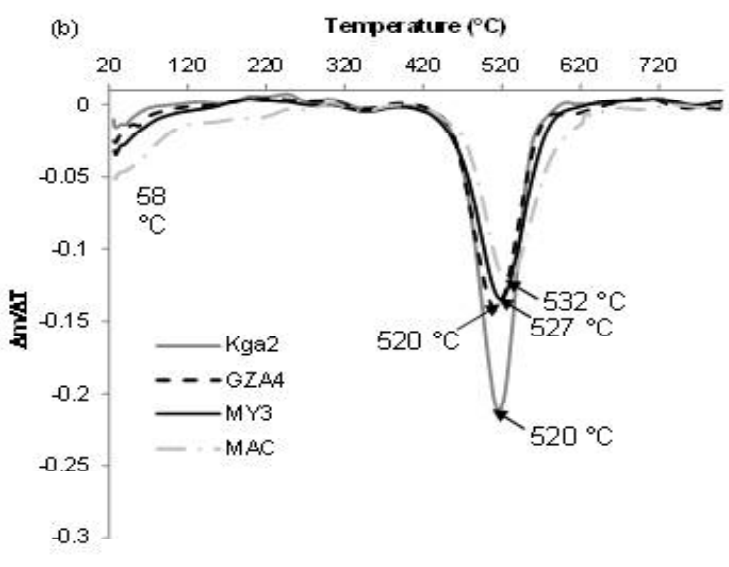

Figure 4: Thermogravimetric analysis of the kaolinites samples: (a) TGA and (b) DTG 

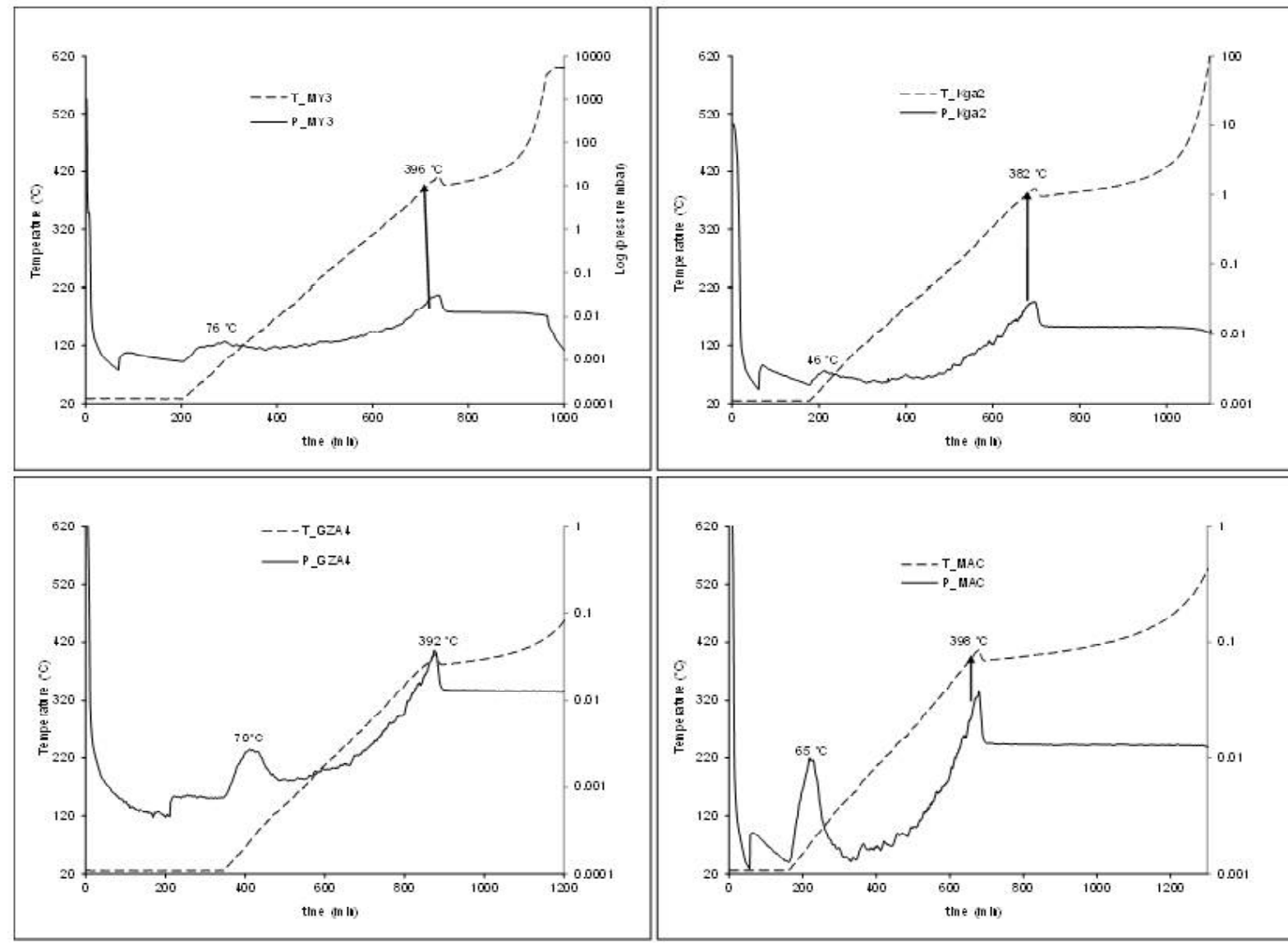

\section{Conclusion}

This work was focussed on the thermal analysis of some kaolinite samples using two different methods: TGA and CRTA. From the results obtained, it is observed that the analysis condition influence the onset of the dehydroxylation. Hence using controlled rate thermal analysis, which operates under high vacuum, enhanced the difference in the dehydroxylation temperature more than the TGA. The crystallinity of the sample influenced the onset of the dehydroxylaion. The dehydroxylation temperature is higher for samples with high crystallinity. In addition, TEM observations and SSA measurements indicated that in addition to the crystallinity, the clay particle size also played a role in controlling the heat diffusion within the clay grain for dehydroxylation to occur. From these results, it is suggested that, crystallinity index together with clay particles size, can be of help in the choice of a kaolinite sample for applications requiring dehydroxylation. Such an approach can help to reduce the onset of the firing, and hence the energy consumption.

Author Contributions: Conceptualization: Mbey; D ata collection: Mbey and Ngally; D ata Analysis and graphs drawing: Mbey, Ngally and Coulibaly; O riginal draft writing: Makon and Mbey; writingreview and editing: Coulibaly S.; Kong S.; Makon and Ngally; Supervision: Kong and Mbey.

Acknowledgement: The authors are grateful to the Cameroon G overnment for the special research allowance to staff of state universities.

Conflicts of Interest: The authors declare no conflict of interest.

\section{References}

Cabedo, L., Giménez, E., Lagaron, J.M., G avara, R., Saura, JJ. (2004). Development of EVOH- 
kaolinite nanocomposites. Polymer, 45, 52335238.

Chen, B., Evans, J.R.G. (2005). Thermoplastic starch-clay nanocomposites and their characteristics. Carbohydrate Pdymes, 61, 455463.

De Carvalho, A.J.F., Curvelo A.A.S., Agnelli, J.A.M. (2001). A first insight on composites of thermoplastic starch and Kaolin. Carbohydrate Pdymes, 45, 189-194.

Djon Li Ndjock, B.I., Robayo-Salazar, R.A., Mejia De Guttierrez, R., Baenla, J., Mbey, J.A., Cyr, M., Elimbi, A. (2021). Phosphoric acid activation of volcanic ashes: Influence of the molar ratio $\mathrm{R}=$ $(\mathrm{MgO}+\mathrm{CaO}) / \mathrm{P}_{2} \mathrm{O}_{5}$ on reactivity of volcanic ash and strength of obtained cementitious material. Jaumal of Building Engineeing 33, 101879.

Ekosse, G.E. (2010). Kaolin deposits and occurrences in Africa: geology, mineralogy and utilization. Applied Clay Sáence, 50, 212-236.

Fadil-D jenabou, S., Ndjigui, P.D., Mbey, J.A. (2015). Morphological and physicochemical characterization of Ngaye alluvial clays (Northern Cameroon) and assessment of its suitability in ceramic production. Journal of Asian Ceramic Soidy, 3, 50-58.

Feylessoufi, A., Villiérias, F., Michot, L.J., De D onato, P., Case, J.M., Richard, P. (1996). Water Environment and Nanostructural Network in a Reactive Powder Concrete. Cement and Conmete Composite, 18, 23-29.

Frost, R.L., Cheng, H., Yang, J., Liu,, Q., He, J. (2010). Thermogravimetric analysis-mass spectrometry (TG-MS) of selected Chinese kaolinites. Thermochimica Acta, 507-508, 106-114.
Frost, R.L., Makó, É., Kristóf, J., Horváth, E., Kloprogge, J.T. (2001). Modiûcation of kaolinite surfaces by mechano-chemical treatment. Langnir, 17, 4731-4738.

Gasparini, E., Tarantino, S.C., G higna, P., Riccardi, M. P., Cedillo-G onzález, E. I., Siligardi, C., Zema, M. (2013). Thermal dehydroxylation of kaolinite under isothermal conditions. Applied Clay Saiene, 80-81, 417-425.

Giese, R.F. (1988). Kaolin Minerals: Structures and Stabilities. In Hydrous Phyllosilicates, pp 2966, ed. S.W. Bailey, Mineralogical Society of America.

Gul, S., Kausar, A., Muhammad, B., Jabeen, S. (2016). Research Progress on Properties and Applications of Polymer/ Clay Nanocomposite. Pdyme-Plastics Techndogy and Engineaing 55, 684703.

Harvey, C.C., Lagaly, G. (2006). Clay in Industry: Conventional application, In Handbook of Clay Sciences (developpment in Clay Sciences), Bergaya F., Theng B.K.G., Lagaly G. (eds), Vol 1, pp 501-540.

Hinckley, D.N. (1963). Variability in 'crystallinity' values among the kaolin deposits of the coastal plain of Georgia and South Carolina: In Clays \& Clay Minerals, Proc. 11th Natl. Conf., O ttawa, O ntario, 1962, W. F. Bradley, ed., Pergamon Press, New York, 229-235.

La Mantia, F.P., Mistretta, M.C., Scaffarol, R., Botta, L., Ceraulo, M. (2015). Processing and characterization of highly oriented fibres of biodegradable nanocomposites. Composites part B: Engineaing 78, 1-7.

Mbey, J.A., Hoppe, S., Thomas, F. (2012). Cassava starch-kaolinite composite film. Effect of clay 
content and clay modification on film properties. Carbohydrate Pdymes 88 (1), 213-22.

Mbey, J. A., Thomas, F., Ngally Sabouang, C. J., Liboum, Njopwouo, D. (2013). An insight on the weakening of the interlayer bonds in a Cameroonian kaolinite through D MSO intercalation. Applied Clay Saiene, 83-84, 327-335.

Mbey, J.A., Thomas, F., (2015). Components interactions controlling starch-kaolinite composite films properties. CarbohydratePdymes $117,739-745$

Mbey, J.A., Thomas, F., Razafitianamaharavo, A., Caillet, C., Villieras, F. (2019). A comparative study of some kaolinites surface properties. Applied Clay Säence, 172, 135-145

Murray, H.H. (1988). K aolin Minerals: their genesis and occurrences. In Hydraus Phyllosilicates pp 67-89, ed. S.W. Bailey, Mineralogical Society of America.

Murray, H.H. (2000). Traditional and new applications of kaolin, smectite, and palygorskite: a general overview. Applied Clay Saience, 17, $207-$ 221.

Ndjigui, P.D., Mbey, J.A., Nzeugang, N.A. (2016). Mineralogical, physical and mechanical features of the ceramic products of the recent alluvial clastic clays from the Ngog-Lituba region, Southern Cameroon. Jarmal of BuildingEngineening 5, 151-157.

Nkoumbou, C., Njoya, A., Grosbois C., Njopwouo, D., Yvon, J., Martin, F. (2009). Kaolin from Mayouom (Western Cameroon): Industrial suitability evaluation. AppliedClay Saience, 43, 118124.

O nana, V.L., Ntouala, R.F.D., Mbey, J.A., Ngo'o Ze, A., Kabeyene, V.K., Ekodeck, G.E. (2019).
Mineralogy and preliminary assessment of the potential uses of alluvial clays from Batouri (Eastern-Cameroon), Cerâmica, 65, 407-415.

Q taitat, M.A., Al-Trawneh, I.N. (2005). Characterization of kaolinite of the Baten ElGhoul region/south Jordan by infrared spectroscopy. Spetrochimica Ada Part A: Mdealar and Biomdeailar Spetroscopy, 61, 1519-1523.

Tchakoute Kouamo, H., Elimbi, A., Mbey, J.A., Ngally, S.C. J., Njopwouo, D. (2012). The effect of adding alumina-oxide to metakaolin and volcanic ash on geopolymers products: A comparative study, Construction and Building Material, 35, 960-969.

Uysal, U.I., Cerri, G., Marcuzzo, E., Cozzolino C.A., Farris, S. (2014). Nanocomposite films and coatings using inorganic nanobuilding blocks (NBB): current applications and future opportunities in the food packaging sector. RSC Advances, 4, 29393-29428.

Zhang, Y., Liu, Q., Wu, Z., Zheng, Q., Cheng, H. (2012). Thermal behavior analysis of kaolinitedimethylsulfoxide intercalation complex. Jaumal of Themal Analalisi and Calorimery., 110, 11671172. 